\section{O imaginário religioso de pacientes de hanseníase: um estudo comparativo entre ex-internos dos asilos de São Paulo e atuais portadores de hanseníase*}

The religious imaginary of Hansen's disease patients: a comparative study of former inmates of the asylums of São Paulo and current Hansen's disease patients

André Gonçalves Mellagi

Psicólogo do Hospital Geral de São Paulo Rua Cerro Corá, 2123/11

05061-450 São Paulo - SP Brasil

andre_mellagi@yahoo.com.br

Yara Nogueira Monteiro

Pesquisadora científica do Instituto de Saúde; coordenadora do Módulo Discriminação/Laboratório de Estudos de Etnicidade, Racismo e Discriminação/Universidade de São Paulo Rua Lasar Segal, 75 Granja Viana - Cotia 06710-810 São Paulo - SP Brasil yaramont@uol.com.br

Recebido para publicação em fevereiro de 2008. Aprovado para publicação em junho de 2008.
MELLAGI, André Gonçalves; MONTEIRO, Yara Nogueira. O imaginário religioso de pacientes de hanseníase: um estudo comparativo entre ex-internos dos asilos de São

Paulo e atuais portadores de

hanseníase. História, Ciências, SaúdeManguinhos, Rio de Janeiro, v.16, n.2 abr.-jun. 2009, p.489-504.

Resumo

Analisa a religiosidade de pacientes portadores de hanseníase que viveram dois períodos distintos da história do tratamento dos doentes: o do internamento em asilos e o da prática atual. Dez entrevistas semiestruturadas focalizaram saúde, religião e hanseníase, abordando os meios de enfrentamento religioso nos dois grupos. No grupo de ex-internos, constatou-se a presença da religião institucionalizada, que atendia aos propósitos de vigilância e da terapêutica isolacionista. Os atuais portadores de hanseníase ainda sentem o peso do estigma da 'lepra' em determinadas situações. Foram aplicados também cinco questionários a profissionais de saúde do DHDS, que apresentam suas considerações sobre a religião do paciente e o tratamento.

Palavras-chave: hanseníase, religião, religiosidade, instituições asilares; São Paulo.

Abstract

The article analyzes the religiosity of Hansen's disease patients who lived during two distinct treatment periods of the sick: that of internment in asylums and the current practice. Ten semi-structured interviews focused on health, religion and Hansen's disease, broaching the ways the two groups faced religion. In the former inmate group, the presence of institutionalized religion was noted, which served the purposes of vigilance and isolationist therapeutics. Present day Hansen's disease patients still feel the stigmatic weight of 'leprosy" in certain situations. Five questionnaires were also given to DHDS health professionals, who presented their considerations concerning the patient's religion and the treatment.

Keywords: Hansen's disease, religion; religiosity; asylum institutions 
$\mathrm{D}$ iante de eventos que desestabilizam seu corpo físico e social, inclusive a doença e a epidemia, o homem lança mão de seu repertório simbólico, culturalmente compartilhado, para dar significado aos fenômenos que perturbam a vida ordinária. $\mathrm{O}$ abalo trazido pela doença pode encontrar sua plena justificativa ao ser inserido num complexo organizado, em que a doença aparece não apenas como evento isolado, mas sim com múltiplas relações com a natureza, o ethos do grupo, a conduta individual e o divino. Além de atribuir significado ao adoecimento, a religião também disponibiliza meios de enfrentamento, de acordo com estudos que a apresentam como algo além de mera escapatória ou fuga de problemas (Pargament, Park, 1995).

A tradição judaico-cristã não deixou de refletir sobre saúde e doença, entrelaçadas na ordem divina e provenientes de graça ou castigo. No mundo antigo, a 'lepra' (termo traduzido da palavra hebraica tsara'ath, presente no Antigo Testamento) ocupa lugar de destaque em meio às demais doenças, marcada por forte conotação de impureza física, espiritual e moral (Cunha, 2005). Desde então, o isolamento tornou-se prática recorrente entre os que portavam sua mácula. Durante a Idade Média, "a lepra representou a grande praga, a sombra sobre todos os dias da humanidade medieval. O medo de todas as outras doenças, juntas, dificilmente se pode comparar ao terror da lepra. Nem mesmo a Peste Negra, no século XIV, ou o aparecimento da sífilis, ao final do século XV, produziram tamanho pavor" (Rosen, 1994, p.59). Nos dias atuais, o estigma da 'lepra' ainda ressoa entre portadores de hanseníase, produzindo iguais reações de raiva, negação, vergonha e culpa (Olivier, 1988).

No contexto latino-americano, mais precisamente colombiano, durante o período colonial, foram as instituições religiosas que tiveram primazia no cuidado aos portadores de hanseníase (Maciel, 2004). A prática de isolar pacientes, herança de antigas tradições religiosas, serviu aos propósitos de manter os doentes afastados (Obregón, 2003), e no século XX o Estado colombiano passou a controlar todos os leprosários que serviam à proposta isolacionista. No Brasil as medidas adotadas pelos meios oficiais de combate à hanseníase trilharam caminho semelhante. Os primeiros hospitais surgiram no século XVIII, com o crescimento da endemia, fruto do esforço de entidades filantrópicas auxiliadas pelo Estado (Monteiro, 1995).

Em São Paulo, os asilos fundados nos séculos XIX e XX "eram instituições cujo objetivo principal era proteger a sociedade sadia do perigo representado pelos doentes" (p.83). O modelo profilático paulista, alicerçado no isolacionismo, consolidou-se entre os anos $20 \mathrm{e}$ 30 com a construção dos grandes asilos-colônia, tais como o Sanatório Padre Bento (em Guarulhos, 1931), o Asilo Santo Ângelo (em Mogi das Cruzes, 1928), Pirapitingui (em Itu, 1931), Cocais (em Casa Branca, 1932) e Aimorés (em Bauru, 1933). O Departamento de Profilaxia da Lepra (DPL), consolidado em 1935, passou a gerenciar toda a rede asilar, concentrando a esfera decisória tanto sobre os procedimentos clínicos como sobre os critérios de isolamento.

O foco deste estudo, de caráter qualitativo e descritivo, está nas relações entre a religiosidade do paciente portador de hanseníase e o processo saúde/doença. Como a hanseníase ainda se vê mesclada dos preconceitos e medos relativos à antiga 'lepra', estigmatizada desde os tempos bíblicos, refletimos sobre as maneiras como os doentes buscam formas de 
entendimento e auxílio pela religião. Tentamos compreender as características dessas relações a partir do mundo vivenciado pelos portadores de hanseníase no estado de São Paulo, tanto pelos que foram limitados às instituições asilares da primeira metade do século XX, quanto pelos pacientes tratados pela terapêutica hoje vigente.

\section{Método}

O principal instrumento de pesquisa foi o depoimento oral. Elaboramos entrevista semiestruturada, salientando tanto aspectos vivenciais do entrevistado ao longo de seu convívio com a hanseníase, quanto sua visão religiosa ou não do mundo e do processo saúde/doença. A colônia entrevistada é de portadores de hanseníase, e a rede ${ }^{1}$ é de exinternos dos asilos do estado de São Paulo e de pessoas com diagnóstico recente de hanseníase. Recolhemos histórias orais de cinco pacientes que viveram a terapêutica isolacionista das instituições totais e de cinco que estão sendo atendidos na Divisão de Hansenologia e Dermatologia Sanitária (DHDS) da Secretaria Estadual de Saúde de São Paulo. Embora com peso menor, também aplicamos um questionário a três médicas e duas auxiliares de enfermagem, visando obter informações sobre as influências da religião no atendimento de pacientes portadores de hanseníase.

Dividimos os entrevistados em grupo A, para os antigos internos, e grupo B, para os atuais portadores de hanseníase, e identificamos suas falas com essas letras seguidas de um número, correspondente a cada um dos depoentes. Pedimos que discorressem sobre alguns temas propostos, tais como diagnóstico da doença, convívio com a hanseníase (dificuldades e os meios para enfrentá-las), religiosidade e opiniões sobre como a religião pode ou não auxiliar em situações de doença. Para os integrantes do grupo A, acrescentamos perguntas referentes à vida asilar (entrada, cotidiano e religião nos asilos) e para os do grupo B, questões a respeito das expectativas para o futuro em relação à doença. Os estilos de enfrentamento religioso, referidos na obra do psicólogo K.I. Pargament (1995, 1997), forneceram o apoio teórico para a descrição dos usos da religiosidade presentes nos relatos recolhidos.

Os profissionais de saúde responderam a perguntas diretas sobre situações em que observaram a religião do paciente interferindo no atendimento, em quais delas a religião prejudicou ou beneficiou a terapêutica atual baseada na poliquimioterapia. Também comentaram suas maiores dificuldades no atendimento a pacientes portadores de hanseníase.

\section{Os entrevistados}

\section{Grupo A: os antigos internos}

As entrevistas foram feitas num pensionato próximo ao Complexo Hospitalar Padre Bento, de Guarulhos, onde moram muitos ex-internos dos antigos asilos de São Paulo. A época de internação vivida pelos cinco portadores de hanseníase compreendeu o período de 1935 a 1962. As informações sobre os entrevistados podem ser consultadas no Quadro 1.

A entrada dos antigos internos nos asilos se deu muitas vezes de forma traumática, tanto para os pacientes quanto para os familiares, que também passavam a compartilhar 
o estigma da 'lepra'. O entrevistado A1, aos 16 anos, após muitos exames com um médico que lhe aplicava injeções contra uma febre desde os oito anos, foi conduzido em camburão até uma estação, onde embarcou num trem para o Asilo-Colônia Cocais. Só tomou conhecimento de que tinha 'lepra' ao ser alertado pelos funcionários do Departamento de Profilaxia da Lepra de que iria contaminar toda a cidade. Sua irmã foi expulsa da escola, e a confeitaria da família teve que ser fechada devido ao boicote dos moradores locais, o que obrigou a família a mudar-se para São Paulo.

A entrevistada A2 percebeu algumas manchas aos 15 anos e aos 19 receber do Departamento o diagnóstico de 'lepra', quando foi internada no Sanatório Padre Bento. Encontrou, no asilo, liberdade para aprender a lidar com enfermagem e exercer sua religiosidade, em comparação ao ambiente repressor que vivia em casa com sua madrasta. A hanseníase, diz ela, foi "uma bênção que Deus me deu".

A mãe de A3 percebeu nela, ainda menina, manchas roxas na pelo de sua perna e seu rosto, e ela já sofria discriminação por parte de alguns parentes, pois o pai, já falecido, também fora interno de Cocais. A mãe e os irmãos mudavam-se com A3 para locais em que não havia muitas pessoas, mas aos 12 anos ela foi denunciada por uma vizinha ao DPL: "O patrão despediu meus irmãos do serviço. Um dia o carro do DPL passou e me pegou. Chegaram dois homens, cochicharam com minha mãe, ela se pôs a chorar. Tinha um oratório onde ela ficou rezando, já arrumando as minhas coisas... não vi nem meus irmãos, que estavam trabalhando".

Com 13 anos, A4 fez exames a pedido do diretor que inspecionava os alunos na escola em que estudava. Com erupções pelo corpo e febre, foi levada ao DPL, de onde partiria para o Asilo Padre Bento.

Já casada e com um filho aos 16 anos, A5 percebeu os primeiros sinais da doença manchas brancas e crespas na sua perna. De Jacareí, onde morava, foi para Pirapitingui e de lá para o asilo de Santo Ângelo. Seus amigos a evitavam, e seu pai precisou voltar a Pindamonhangaba, cidade natal de A5, onde ninguém sabia a respeito da moléstia que acometera sua filha.

O novo cotidiano do qual os portadores de hanseníase passavam a fazer parte era amparado pela prática isolacionista, que procurava mantê-los sem contato com o mundo sadio. Os que não possuíam recursos para melhor alimentação e moradia tinham que trabalhar nos asilos, sendo comum a equipe profissional ser formada também por doentes. A1 trabalhou no escritório de um diretor clínico em Cocais e depois foi nomeado diretor

Quadro 1 - Os antigos internos

\begin{tabular}{ccclll}
\hline Entrevistado & Sexo & Idade & \multicolumn{1}{c}{ Asilos } & $\begin{array}{c}\text { Tempo de } \\
\text { permanência }\end{array}$ & Religião \\
\hline A1 & M & 82 & Cocais, Padre Bento & 2 anos, 11 anos & sem religião \\
A2 & F & 83 & Padre Bento & 22 anos & católica \\
A3 & F & 70 & Cocais, Padre Bento & 10 anos, 9 anos & católica e espírita \\
A4 & F & 79 & Padre Bento & 18 anos & católica \\
A5 & F & 82 & Pirapitingui, & 2 meses, 12 anos & católica e espírita \\
\end{tabular}


do clube da Caixa Beneficente de Padre Bento, criada para atender aos interesses dos doentes. A2 começou a cuidar das crianças no pavilhão dos menores e depois aprendeu técnicas de enfermagem. A3 atuou como enfermeira e ajudava na rádio do asilo. A4 trabalhou na lavanderia e prestou serviços na enfermaria. A5 era cozinheira no pavilhão dos menores.

O contato com familiares se fazia por visitas e cartas, desinfetadas antes de ser enviadas. A1 conta que, em Cocais, o encontro com os parentes se dava num parlatório que separava os internos das pessoas provenientes do mundo externo. Além do sofrimento da doença, a perda dos vínculos transparece em grande parte das entrevistas. Isso favorecia as fugas e consequentemente as punições, que também eram aplicadas a qualquer desobediência às normas da sociedade disciplinar. Atesta A5: "fugi pra ver meus filhos ... . Quando cheguei lá fui direto pra cadeia. Peguei um ano de cadeia, fui pra cadeia pra morrer. Lá não me davam comida, passavam da hora, não tinha água pra beber, acabei caindo de cama".

Muitos doentes não conheciam o termo lepra devido à pouca idade e instrução, na época em que entraram no asilo. A4, porém, conta que a palavra morfético fez com que sentisse medo da doença que portava. Segundo A1, a discriminação também era promovida pelos órgãos oficiais do estado, que quebravam os copos utilizados pelos pacientes e espalhavam o medo para incitar, junto à população, a denúncia de doentes.

Os remédios ministrados aos internos eram paliativos e causavam dores e febres. A doença evoluía, e os mais debilitados eram transferidos para outros asilos, o que causava revolta e até suicídios entre os doentes. A1 foi perdendo a visão até ficar cego. A2 tinha caroços vermelhos nas pernas e sofreu reações aos remédios prescritos na época e dores por dez anos. Outros também relataram experiências dolorosas da doença como as principais dificuldades. A4 acrescenta a elas as dificuldades de convivência com outros pacientes. As diversões e o trabalho nos asilos ajudavam a esquecer a doença, informa a maioria dos depoimentos.

\section{Grupo B: os atuais portadores de hanseníase}

Os pacientes entrevistados no DHDS portam a hanseníase dos tipos clínicos multibacilares (dimorfa e virchowiana) e paucibacilares (indeterminada e tuberculóide). As primeiras necessitam tratamento mais prolongado do que as últimas. Além disso, a clofazimina, medicamento de que fazem uso, escurece a pele devido à reação do corante nas glândulas de gordura. Outras informações sobre os entrevistados encontram-se no Quadro 2.

Quadro 2 - Os atuais portadores de hanseníase

\begin{tabular}{cccccc}
\hline Entrevistado & Sexo & Idade & $\begin{array}{c}\text { Tempo de } \\
\text { tratamento }\end{array}$ & Tipo Hansen & Religião \\
\hline B1 & M & 47 & 1 ano e 6 meses & virchowiana & católica \\
B2 & F & 64 & 3 anos & dimorfa & evangélica \\
B3 & M & 28 & 1 ano e 6 meses & dimorfa & evangélica \\
B4 & F & 31 & 2 anos & dimorfa & católica \\
B5 & M & 51 & 2 anos & & do sétimo dia \\
\hline
\end{tabular}


Ao analisarmos a questão do diagnóstico, identificamos diferentes problemas que acarretaram o retardo do tratamento, o que demonstra que, embora o Brasil seja um país endêmico, ainda ocorre despreparo de profissionais. B2 conhecia a antiga 'lepra' e ficou aliviada ao saber que há possibilidade de cura se forem usados os remédios prescritos. Os médicos com quem se consultara, porém, não detectaram a doença e ela estava bastante comprometida no início do tratamento. A gravidade da doença, aliada a uma infecção na garganta, a manteve internada durante 15 dias no Hospital das Clínicas.

B3 procurou um centro de saúde, indicado por seu patrão, ao perceber manchas no corpo, e foi orientado pelo médico a manter sigilo.

B4, após passar por diversos médicos para tratar manchas na perna, dormência e coceira nas mãos, foi ao Hospital Emílio Ribas, onde foi diagnosticada a hanseníase. Ao saber da doença ficou chocada e com raiva de si; em sua opinião, o doente deveria isolar-se na montanha.

B5 havia percebido manchas e sentido dormência nos cotovelos e joelhos desde 1991. Só em 1999, quando tinha dormências no rosto, foi encaminhado ao DHDS e a hanseníase, diagnosticada. Procurou o tratamento estimulado por campanha veiculada na televisão. Pudemos também verificar a ausência de conhecimentos básicos sobre a doença, a exemplo de B1, que desconhecia alguns sintomas da hanseníase, como a perda da sensibilidade.

As entrevistas realizadas evidenciaram a percepção do preconceito contra a doença e discriminação contra o doente, e como essas questões se revelam no cotidiano dos entrevistados, levando-os a tomar atitudes como evitar comentar sua doença. B1 percebe esse preconceito quando depara com situações em que as pessoas, devido ao escurecimento de sua pele, especulam sobre a doença que o está acometendo. Afirma que a hanseníase difere de outras doenças por ser "uma doença que assusta". B2 pediu demissão de seu emprego de polidora numa fábrica porque as encarregadas a rejeitavam, ainda que as colegas mais próximas não tivessem essa atitude. Já B3 percebe o estigma de suas manchas quando as expõe, havendo quem se afaste ainda que ele explique a causa das marcas. B4 enfatiza que algumas pessoas que lhe eram próximas se afastaram ou alertavam outras a manter distância. Até hoje evita namorar, por medo da rejeição. Há também atitudes pró-ativas, a exemplo de pacientes que levam a seus familiares livros e panfletos que esclarecem sobre tratamento e risco de contágio. B5, por exemplo, avisou os familiares ao ser informado de seu diagnóstico e não se assustou, por considerar que os tempos de agora são outros.

As dificuldades decorrentes de dor e incapacidade evidenciam diferentes formas de tentar a superação e/ou convívio com a doença. B1 relatou que, mesmo com dores e inchaços nas juntas dos membros, não teve complicações em suas tarefas de chaveiro, e o que o ajuda a conviver com a hanseníase é a fé na melhora, bem como a família e suas metas na vida. B2 declara que uma inflamação nos nervos dificulta seus serviços domésticos, mas afirma que, agora que sua pele voltou ao normal, convive bem com a doença; o que ajuda "é força de vontade, fé em Deus". B3 só enfrenta um problema: suas manchas. Não sente dor e encontra alívio no trabalho e no lazer: "Eu esqueço da doença, só me lembro quando tenho que tomar meu remédio, tenho que ir todo mês fazer o exame. Fora isso tenho um monte de outras coisas para pensar, então é melhor não encanar. Se a gente for encanar, fica na neurose, e aí que a doença não para mesmo". B4 perdeu a mobilidade da mão direita, 
ficando impossibilitada de trabalhar e fazer tarefas cotidianas, necessitando, portanto, da ajuda de terceiros. A imobilidade a deixa nervosa, e ela chegou a entrar em depressão, em parte também devido às reações fortes da medicação. Diz que paciência, fé em Deus e os remédios ajudam a enfrentar as dificuldades. B5 começou a sentir dores musculares um mês antes da entrevista e afirma que consegue alívio quando faz algo para esquecer a dor.

\section{Os profissionais de saúde}

O questionário aplicado aos profissionais de saúde indagou sobre as dificuldades no atendimento a portadores de hanseníase, mais especificamente se deparavam, no tratamento, com interferência (positiva ou negativa) da religião do paciente. Pediu-se também que tecessem considerações pessoais a respeito das relações entre saúde e religião. O questionário foi respondido por duas auxiliares de enfermagem, que possuem cerca de oito anos e meio de experiência no atendimento de pacientes de hanseníase, e por três médicas dermatologistas, com experiência de 18 anos em média de clínica em hanseníase. Suas respostas encontram-se aliadas à análise dos relatos dos pacientes, nas considerações finais deste artigo.

\section{Os antigos internos e a religiosidade}

As relações entre religião e saúde, na época de isolamento dos ex-internos, se entrelaçam ao próprio cotidiano. Ao lado das atividades transpostas da sociedade livre para o microcosmo da instituição total (Goffman, 1987) - como o lazer e o trabalho - e do convívio social, a vida religiosa estava presente, tudo sob controle da organização asilar: "A internação ocasionava, por um lado, a interrupção brusca com a vida anterior e obrigava a pessoa a conviver dentro de uma cidade cercada, habitada pela doença, onde, ao lado da ruptura com os usos cotidianos, era imposta uma nova rotina de vida, deliberada por outros" (Monteiro, 1995, p.283). Nos asilos havia igrejas católicas e evangélicas, centros espíritas e templos de outras crenças religiosas. A liberdade de culto favorecia a inserção dos internos nos asilos, além de criar um local de refúgio em meio ao sofrimento causado pela doença e pelo isolamento.

Os sacerdotes também eram doentes, o que fortalecia a nova identidade ao mundo da 'lepra', que o indivíduo passava a integrar. Os horários dos cultos e outros eventos religiosos eram controlados pelo sistema organizacional, que também impunha sua disciplina às práticas espirituais. Muitas vezes os internos eram obrigados a participar dos eventos religiosos ainda que não professassem nenhuma religião, como relata A1: "em Padre Bento tem até hoje uma igreja católica - tinha um padre que era doente também - e um centro espírita. $\mathrm{O}$ pessoal ia à missa, nos velórios, nas festividades religiosas. A gente era obrigado a fazer um serão na Semana Santa; você era escalado, mesmo que não tivesse religião". A5 também relata a obrigatoriedade de participar dos cultos em Santo Ângelo: "Lá eles obrigavam a ir à missa todo dia. As freiras passavam de porta em porta pra ver se as camas estavam arrumadas. Eu não gostava muito de ir à missa e me deitava debaixo da cama, para fugir".

No Sanatório Padre Bento, em torno de uma igreja católica e um centro espírita, havia quermesses, missas e outras festividades religiosas. Em Cocais havia apenas igreja católica, 
e as crianças eram chamadas a frequentar as missas e demais eventos, como reporta A3: "Lá em Cocais era tudo católico. Tinha igreja, tinha padre que era doente também. Tinha dia que eu gostava, outros não gostava de ir à igreja. Tinha dia que ele dava sermão repreendendo a gente, e eu não gostava. A gente era criança e acompanhava a diretora ... só não ia à igreja quando estava doente. A gente acordava de manhã, praticava esporte e ia às cinco e meia da manhã pra missa".

Os padres detinham certo poder sobre os fiéis, servindo aos propósitos de vigilância da gerência sobre os pacientes. Conta A1 que "o padre exercia muita influência, e as pessoas que ele indicava como rebeldes eram consideradas sempre rebeldes, o que não aconteceu comigo, pois eu tinha proteção; fui logo diretor do serviço social". A presença do espiritismo kardecista nos asilos implicava em outras formas de inserção e de apoio material, como comentada por A1: "Recebíamos muitas caravanas de espíritas, que iam nos hospitais e que vão até hoje com frequência. Conheciam os membros, um por um, dos hospitais, levavam presentes, perguntavam se precisávamos de alguma coisa". Vê-se portanto que, se por um lado os mecanismos de controle interno dos asilos eram manipulados por religiosos, por outro as organizações religiosas ofereciam apoio social.

A prática religiosa nos asilos procurava aproximar-se da prática religiosa na sociedade reproduzindo seus modelos e ritos. Horários de missa, procissões, dias consagrados aos santos do catolicismo, tudo se conformava ao que era praticado fora dos limites dos asilos, como enfatiza A4: "A vida religiosa no asilo era aquele negócio de igreja mesmo, tinha missa, procissão... o ritual que tinha fora tinha lá dentro". Contudo o ambiente voltado ao tratamento de doentes fazia com que adequações fossem implementadas às diferentes situações do internamento, com a participação dos internos, como conta A3: "Quando morria gente e não tinha ninguém para acompanhar o enterro, ia um da diretoria lá na escola pedir para as crianças serem dispensadas para acompanhar o enterro". Outra prática, narrada por A3, era levar a comunhão até os pacientes acamados, na enfermaria, uma vez por mês, o que a entrevistada tinha o costume de fazer desde pequena: "Naquele tempo a gente ia na missa em jejum". A2 também participava desse atendimento aos doentes mais graves: "Tinha um lugar onde ficavam os doentes muito ruins, e eu vivia lá visitando eles; preparava para comungar e tudo. Tinha uma equipe de meninas que andavam comigo, pois não podia fazer tudo sozinha".

A relação entre a religiosidade dos pacientes e a entrada nos asilos se configura de diversas maneiras. Há quem tenha mantido suas convicções anteriores à moléstia e à entrada no asilo, sejam elas crenças religiosas ou não. Alguns já frequentavam igrejas, outros acreditavam em dogmas religiosos e guardavam suas posições durante o internamento. É o caso de A1, que apesar de frequentar a igreja do Sanatório Padre Bento por obrigação, nunca praticou qualquer religião mesmo após a saída do asilo. Há também quem tenha entrado em contato, no asilo, com alguma doutrina religiosa que aos poucos foi fazendo parte de sua vida, como indica o depoimento de A5: "No asilo eu não tinha contato com o centro espírita, mas - engraçado - tinha a cama em que eu dormia, atrás da porta, e tinha sempre um pretinho velho que entrava e sentava ao pé da minha cama ... Agora faz tempo que não vejo a aparição. Eu não tinha conhecimento de nada, fui criada na roça, não tinha noção do que era espírito". A5 morou na casa do diretor-presidente do centro 
espírita de Santo Ângelo e o ajudava nas atividades do local, mas não o frequentava. Atualmente, entretanto, frequenta o centro espírita perto do pensionato em que mora: "Aos domingos vou na capela aqui, e sempre que posso vou tomar passe lá no centro espírita". A3 também menciona aproximação com o espiritismo, no seu caso mediada pelo marido, que conheceu no asilo: "Em Cocais eu rezava, eu mesma, e também gostava de ajudar os outros e gosto até hoje. Fui adquirindo esse gosto, que a gente precisava ajudar o próximo. Com meu marido, tinha dia que eu gostava ir tomar passe, mas tinha dia que eu não gostava".

Outro modo de envolvimento com a religião durante o internamento é o fortalecimento da fé demonstrado pela assiduidade aos cultos, missas, orações. A2 relata sua história no asilo salientando que ali encontrou o espaço para a prática de sua religiosidade: "Quando cheguei no sanatório de manhã, eu já queria saber onde era a igreja e comecei a frequentar. Aqui no sanatório dei expansão a minha religião; eu fazia o que eu queria. Em casa eu trabalhava durante a semana, e minha madrasta não deixava eu ir". Enfim, outro modo que poderíamos identificar, nas entrevistas, de envolvimento religioso na época do isolamento é descrito por A4, que comenta seu afastamento da religião a partir da internação: "Pra mim o padre era um santo, do jeito que era antigamente no colégio de freiras, era uma coisa tremenda! Era pecado olhar no espelho, as janelas eram de grade de madeira alta porque não podia olhar pra rua. ... Mas quando cheguei aqui, que encontrei o padre, eu me desiludi. Porque eu era completamente ingênua, eu era boba de tudo, de tudo mesmo. Vendo o comportamento dele me desiludi de tudo, me afastei da igreja. Depois que saí de lá eu retornei".

A análise das entrevistas demonstrou que as formas e práticas religiosas, sejam elas institucionalizadas ou particulares, exercidas após a entrada nos asilos, bem como a vivência da religiosidade não ocorreram de forma homogêna. Considerando os modos de envolvimento com a religião a partir da entrada nos asilos, seja a manutenção de antigas relações, a descoberta de novas práticas, o fortalecimento da fé ou o descontentamento com as instituições (sem que no entanto isso diminuísse a religiosidade pessoal) podemos verificar que todos se referem à história anterior que cada um leva ao interior dos asilos, a instituição asilar em si (incluindo a religião institucionalizada na organização asilar) e a história que vai sendo percorrida ao longo dos anos de isolamento. Entre os entrevistados, apenas um declarou "não ter religião", porém foi justamente ele que apontou "benefícios" e a importância do exercício de algum tipo de religião ou da fé na vida do paciente asilado.

Ainda que a religião, dentro dos asilos, mantivesse o esquema da sociedade disciplinar (Foucault, 1999), domesticando o corpo doente nos rituais prescritos e servindo como desdobramento dos órgãos de vigilância, a história dos entrevistados traça caminhos menos rígidos de prática religiosa. Mesmo aqueles que mais se adaptaram à instituição também buscavam maneiras próprias de exercer sua religiosidade. As orações e o contato com o mundo espiritual fora dos rituais coletivos expressam maior envolvimento individual com esse universo, utilizando-se seus recursos para encontrar respostas aos anseios particulares. A2 afirma: "Gosto de ir lá [na igreja] quando não tem ninguém. Converso com Deus como se estivesse conversando com você". Os entrevistados que possuíam credos diferentes daqueles da maioria também procuravam meios alternativos que coadunam com crença mais 
individualizada, como aponta A5: "Eu sigo o catolicismo, mas creio muito na espiritualidade da pessoa, creio mais numa vida após a morte, não sei te explicar. Não sigo nada; quando eu podia ler, eu lia muito sobre religião espírita, que é uma filosofia de vida ... . Eu não tenho uma religião definida, creio em Deus, Pai todo-poderoso e em Jesus Cristo". A4, desapontada com o esquema da religião oficializada e com as pessoas que a representavam, informa ter sido sempre católica, tendo deixado de comungar e confessar durante o período de internação no Sanatório Padre Bento e só retomando essas práticas quando já morava no pensionato onde vive atualmente, muitos anos após sua alta. Durante o período de internamento, lembra A4, "eu rezava, mas não na igreja. Me desiludi mais com a religião, com os padres, com as freiras. Nas festas religiosas eu ia mais com o grupinho, para brincar".

Maneiras próprias de praticar a religião percorrem os depoimentos. A2 trabalhava no atendimento a outros doentes e também era solicitada a fazer novenas e rezas para os pacientes mais graves, prática que mantém atualmente no pensionato em que convive com outros antigos pacientes: "Frequentei a religião como eu gosto. Aqui, quando estou disposta, vou visitar um doente ou outro ... . Rezo meu terço todo dia, rezo o rosário do jaculatório quando estou boa. Procuro fazer tudo de cada vez. Uma promessa que fiz, na ocasião em que um amigo nosso ficou cego da doença, há muitos anos". A3 diz que pede para Deus ajudá-la quando está doente, rezando o pai-nosso e ave-maria: "Se eu merecer, eu peço sempre; se eu não merecer, que me dê forças também. Eu encontrei apoio espiritual nas comunidades religiosas, aqui no pensionato se a gente fica doente as meninas socorrem a gente". A4 comenta seu retorno à religião no pensionato, onde voltou a rezar, comungar, confessar e frequentar a missa todos os dias. Já com A5, o contato com a espiritualidade se dá com pedidos a Deus para que melhore a saúde das pessoas e para que assista seu filho.

Interrogados sobre como a religião os poderia beneficiar em situações de doença, apontam que a vida asilar e o tratamento terapêutico da época não se dissociam dessas visões, compartilhando, pelo contrário, o modo como o sofrimento pode ser ou não aliviado mediante solicitação espiritual. Embora A1 não pratique nenhuma religião, sua opinião é de que uma crença pode beneficiar, dando significado à doença na vida do indivíduo: "A religião pode beneficiar, pois leva à cabeça do paciente a ideia de que a doença, conforme os espíritas dizem, é o carma; conforme a religião católica, é uma doença que você sofreu e que vai mais depressa subir para o Paraíso". A possibilidade de encontrar, na religião, meios de enfrentamento da doença é apontada por A3, ao afirmar que "a religião pode beneficiar assim: a gente tem mais fé, tem mais força para suportar as dores, a doença que vem, a gente fica mais preparada. E se a gente não acredita em Deus, não tem fé, nada vale".

Outro ponto de auxílio fornecido pelos preceitos religiosos diz respeito às normas de conduta que o dogma estabelece. Segundo A5, paralelamente ao tratamento médico, devese tratar do corpo e da alma também, ter boas ideias, sem desejar mal a ninguém, sob o risco de esses desejos voltarem em dobro para quem os pensou. Também beneficia "no modo de a pessoa pensar e viver, não ter ganância por dinheiro, não ter rancor do outro". A2, por sua vez, salientou suas experiências revelando como seus pedidos, feitos em rezas e promessas, auxiliaram sua saúde e de outros doentes, além de testemunhar casos de conversão de pacientes terminais, prevalecendo nessas ocorrências a importância do contato com o mundo espiritual, ainda que a morte sobrevenha pouco tempo depois. A entrevistada 
almejava uma saúde mais "metafísica" quando encaminhava as pessoas que atendia para a morte sem dor através da comunhão em Deus. Os anseios que a entrevistada solicitava ao plano espiritual, incluindo suas atividades no atendimento de outros doentes, têm por objetivo mais o conforto na esfera do além-mundo do que a satisfação das necessidades imediatas. Numa de suas falas, A2 recorda: "Meu pai dizia para mim que eu semeio todo dia uma muda de rosa e que iria colher um ramalhete. E é verdade. Se você faz uma coisa boa, está guardado lá em cima".

Outros entrevistados, porém, não atribuem papel significativo à religião na situação vivida pelos portadores de hanseníase nos asilos. A4 esclarece sua opinião: "Acho que a religião pode beneficiar bem pouco. A gente reza, pede, tem aquela fé e tudo mais, mas a doença está ali, a dor está ali, e não é porque você está pedindo que ela vai sair dali ... . Você rezando ou sem rezar, o que tiver que passar você passa". O conforto dos asilos também não contribui para a melhora da saúde, uma vez que o sofrimento permanece, nas considerações de A4. A vida asilar é também mencionada junto ao fracasso do papel da religião, por A3: "A gente também passou por muita coisa, via muita coisa errada ... ficou meio desacreditada com a religião. Mas eu tenho fé". Deparamo-nos com a diferenciação entre religião e espiritualidade, salientada pelos próprios entrevistados. Entendemos por religião um sistema organizado de crenças, práticas, rituais e símbolos, destinado a facilitar a proximidade com o sagrado e promover relações entre membros de uma comunidade. Quanto a espiritualidade, trata-se de busca pessoal por respostas às questões fundamentais da vida, do significado e das relações com o sagrado ou transcendente (Koenig, McCullough e Larson, 2001); entre essas questões fundamentais está o processo saúde/doença.

\section{Os atuais portadores de hanseníase e a religiosidade}

A religiosidade dos atuais portadores de hanseníase e a forma como que ela se coloca perante a saúde e da doença também se configuram de diversas maneiras, dependendo da história de vida de cada um e do alcance que a hanseníase teve nesse percurso. A nova terapêutica, adotada desde a superação do isolacionismo, possibilitou maior esclarecimento da doença para a sociedade e o início da luta contra a estigmatização. Campanhas são veiculadas com o propósito de alertar as pessoas quanto aos sintomas, divulgando, ao mesmo tempo, a possibilidade de cura da hanseníase. O abandono, pelos órgãos oficiais, do antigo termo 'lepra' visa conscientizar a população sobre os perigos efetivos da doença sem o alarmismo carregado de medo e de rechaço aos doentes.

A segunda parte da pesquisa consistiu em verificar o papel da religião nessa fase de mudança da terapêutica, como o indivíduo lida, no âmbito religioso, com a nova visão da hanseníase, quando se abole a segregação dos infectados. O que se verificou, nas entrevistas, é que há mais certeza na cura e reabilitação do que ocorria entre os antigos internos, que entravam nos asilos sem esperanças de sair de lá. Isso, porém, não minimiza a gravidade da doença e dos problemas que ela acarreta, persistindo a estigmatização.

B1 informa que sempre foi católico, mas já visitou igrejas evangélicas convidado por amigos. Sua predileção pelo catolicismo se explica por achá-lo mais tranquilo e encontrar na igreja conforto espiritual, aos domingos e às vezes durante a semana. Ele também 
procura contato próprio com o mundo espiritual, pedindo a Deus para ajudá-lo a enfrentar os obstáculos do dia-a-dia. E reflete: "O que é uma reza? Aquilo tudo que está escrito ou o pensamento que você eleva até sua crença, seu Deus?". Considera que as pessoas buscam o auxílio divino ao se encontrar em circunstâncias difíceis: "Acho que Deus me ouviu; as coisas nesses últimos dois, três anos começaram a dar uma clareada". O hábito de recorrer à religião em situação de doença faz parte da cultura de sua família desde que ele era pequeno, e sua mãe costumava benzer as crianças. Diz que encontra apoio na igreja, mas não comentou com ninguém a respeito da hanseníase. Não houve mudança em sua vida religiosa depois da doença, sua fé não aumentou nem diminuiu. Ele pede para se fortalecer da mesma forma que antes. Acredita "que a fé é tudo; sem fé você morre. Fé no seu trabalho, nas suas coisas; só a fé te ajuda a seguir, a combater. Acho que a fé espiritual cria defesa no seu organismo. Também se você está empenhado em alguma coisa, sua meta, ... no final acaba sendo pela fé mesmo". Aflora, dessa forma, o papel que tem a fé no enfrentamento da doença, bem como, de resto, em outros aspectos da vida.

B2 informa ter-se convertido à religião evangélica depois de saber-se portadora de hanseníase. Sem encontrar solução para seu problema, passou a frequentar a igreja e fazer campanhas de oração até conseguir ser tratada por um médico, que lhe receitou os remédios. Percebe-se assim uma mudança na vida religiosa decorrente da doença, posto que antes era católica, fazia promessas a Nossa Senhora Aparecida caso estivesse ela ou algum familiar doente, e foi a um "centro de macumba" para tentar eliminar a doença que atacava sua pele antes de haver a sua conversão. A análise da trajetória de B2 evidencia a existência de intenso trânsito religioso, na busca de uma opção religiosa que lhe auxiliasse no enfrentamento da doença. Revela que ainda vai à missa aos domingos, mas destaca o fato de que explica-se a Bíblia na igreja evangélica, a qual frequenta aos domingos, sextas e quartas. Diz orar toda hora e em qualquer lugar; sua oração "é pedir o que você tem vontade pra Deus, não é pai-nosso, ave-maria, essas coisas não". Justifica sua conversão pela dor por que passou quando a hanseníase marcou sua pele. E afirma encontrar apoio na igreja que frequenta, onde todos sabem que ela teve a doença. $\mathrm{B} 2$ também acha que a religião pode beneficiar através da fé "de que Jesus existe vivo e não morto". A entrevistada trouxe os termos inscritos na Bíblia ao se referir à antiga 'lepra' em sua concepção de impureza, de imundície: "Deus me pôs limpa no mundo, então ele vai me limpar também".

Outro benefício da religião à saúde é, para B2, a força de vontade, pois "se Ele está te dando aquilo ali, uma esperança, e você não reage, o que você quer? Afundar. Então é preciso ter muita força de vontade também, pois se você se deixar cair, cai de uma vez no buraco". Tais considerações ilustram uma concepção partilhada por grande parte dos entrevistados, a de que não se delega inteiramente a uma entidade divina a promoção da saúde, devendo-se acrescentar a participação do indivíduo em seu processo de cura, por meio do cumprimento das prescrições médicas. Essa concepção corresponde à descrição do estilo de enfrentamento religioso que Pargament (1997) define como cooperativo (collaborative), em que esforço pessoal é aliado à ajuda divina. Isso é também reiterado no depoimento de B3: "Não adianta nada ter fé em Deus e não tomar o remédio. Eu tenho muita fé em Deus, mas tenho que tomar os remédios, senão fica difícil. Então acho que a gente tem que agir com prudência. Os médicos estão aqui pra isso, e Deus é que põe a mão 
em cima pra que a gente tenha melhora através do remédio que a gente toma ou da orientação médica".

O entrevistado B3 é evangélico desde os 18 anos e participa dos cultos semanais, nas igrejas Assembleia de Deus e Renascer em Cristo, ou em casas de outros membros. Faz campanha de oração aos sábados, durante um ou dois meses, além de jejuns e vigílias noturnas. Vai também ao monte, que é um culto noturno afastado da cidade onde cantam-se hinos e falase sob glossolalia. Quanto à importância da religião diante de situações de doença, afirma que "a gente tem uma fé e ... tem que seguir esta fé, pois se não houver essa fé a gente não chega a lugar algum. Por isso quando a gente está doente, ou não, mais do que nunca tem que ter fé e pedir muito para que Deus livre a gente do problema. A gente também ora para outras pessoas que estejam enfermas". Declara encontrar apoio na igreja, em que os presbíteros fazem uma corrente de oração para as pessoas doentes. Entretanto só o pastor de sua igreja conhece a especificidade de sua doença: "a gente não fala exatamente assim sobre a doença, pois mesmo dentro da igreja existem pessoas que se afastam por algum motivo. Então a gente escolhe uma pessoa, fala que está enfermo, mas não fala qual é o problema. "Se falamos 'lepra', aí todo mundo sabe que é muito antiga; o pessoal tem medo, receio. Mas quando falamos 'hanseníase', pouquíssimas pessoas sabem o que é". Não houve mudança em sua vida religiosa depois que a doença se manifestou, pois acredita que seja uma provação que fez aumentar sua fé. Cita casos de pessoas que aceitaram a religião evangélica, perderam tudo o que tinham, mas que logo recuperaram por não abandonar a fé. Diz que ora com mais intensidade. Em sua opinião, não é a religião que beneficia a saúde da pessoa, mas a fé, pois "Não adianta nada ... ser evangélico, estar indo na igreja o tempo todo se ... não tem fé, entendeu? Isso acontece muito. Pode pedir orações, fazer o que for, que não resolve o problema dele ... Então essa fé que eu tenho que influencia meu problema, minha doença. E com certeza sei que Deus vai me tirar dessa, pois tenho fé nele. Então não adianta religião". Concorda, portanto, com a distinção clara entre fé e religião também defendida por B1: "Só a fé ajuda mesmo. Na religião, se você não tiver fé, não adianta... é complicado".

B4 conta que a fizeram católica desde pequena. Frequenta a festa de Santo Expedito no dia 19 de abril, já foi a Aparecida do Norte com os membros da igreja e reza todos os dias. Assim como B1, declarou que a procura de amparo religioso se dá em geral nas situações mais difíceis, Relata que quando está doente fica mais perto de Deus, rezando e lendo um salmo ou a Bíblia durante o dia. Já fez promessas quando morava no Nordeste, mas agora só faz "promessa pequena", com pedidos para se recuperar da doença. Foi em casa de benzedor, porém sem dar muito crédito aos conselhos dele, que "mandou a gente lavar três dias com sal grosso. Achei engraçado. Não acredito em nada não, mas mesmo assim eu fiz por causa que dizem que desincha os pés, pois estava com os pés inchados". B4 não revelou estar doente aos membros de sua igreja, que só frequenta nas missas. Não mudou sua vida religiosa depois da doença, mas acredita no auxílio divino. Em sua opinião, a religião pode beneficiar pois "muda a cabeça da gente". Devido às reações ao medicamento, escurecimento da pele e aumento de peso, a entrevistada entrou em depressão, o que a impedia de sair como fazia antes. Conta que muitas vezes deixou de ir à igreja por não ter roupa que lhe servisse, o que lhe abatia o ânimo: "Eu chegava a falar que iria tomar os remédios tudo de uma vez. Falava besteira, não estava com vontade de nada. Isso mudou 
muito a minha cabeça. Mas eu acreditei, todo mundo falava 'reza bastante, faz isso, faz aquilo', e depois melhorei. Não voltei a ser como antes, mas melhorei, porque não tinha vontade pra nada. Quando achei que estava com depressão mesmo tive que mudar, senão a casa caía". Se a religião não interfere diretamente na hanseníase, os problemas que ela pode causar, como a depressão de B4, podem ser aliviados pela busca de conforto que permita recuperar o ânimo e o tratamento adequado.

B5 era católico por exigência familiar e se converteu há dois anos à Igreja Adventista do Sétimo Dia. Sua principal motivação foi a mudança de estilo de vida, além de encontrar ali uma doutrina que pede mais a participação de seus membros, sem destacar a figura de um sacerdote. Segundo B5, "essa doutrina se preocupa muito com a saúde - 'não beba, não fume, não tome café, isso tudo prejudica o corpo e o espírito'. Sou praticante, vou à Igreja Adventista do Sétimo Dia, todas as quartas, sábados, domingos e, se precisar, todo o dia". A mudança em sua alimentação fez com que perdesse peso, e B5 salienta os pontos positivos à saúde, com a adoção das regras de conduta que a doutrina sublinha. Participa de reuniões, brincadeiras com os jovens, excursões em acampamentos e ajuda humanitária. Afirma orar todo dia e toda hora: "A oração é conversar com Deus, não é repetir. O que você precisa o teu Pai sabe. Agora, pede que ele dá. Então orar não tem coisa repetitiva, coisa escrita, nada. É você conversar com Deus, como você conversa com um amigo". Diz que "na hora do perigo, que você precisa, você não se lembra nem de orar e nem de Deus. Então a gente tem que agradecer". Essas palavras se diferenciam daquelas de B1 e B4, que consideram que as pessoas só se lembram de Deus quando necessitam ser socorridas. Em situação de doença, declara, "eu recorro a Deus, sim, mas eu procuro a medicina. Pensamento meu, não é da igreja". Considera que milagres acontecem nas mãos dos médicos, citando a antiga operação que tinha feito no intestino, na época em que detectara a hanseníase, acreditando na predestinação do médico habilitado a operá-lo: "Tenho certeza que ele também recorre a Deus quando vai fazer a operação", conclui. B5 menciona que encontra apoio em sua igreja, no que diz respeito à sua doença. Levou um panfleto do DHDS, com explicações sobre a hanseníase, a sua comunidade religiosa. Apesar de muitos se terem assustado, ela acha importante esclarecer as pessoas, para que se cuidem. Não percebeu preconceito por parte dos membros da igreja. Sua vida religiosa também não foi afetada pela hanseníase, nem aumentou sua participação em cultos depois da doença. Partilha da visão de outros entrevistados quanto à crença de que, pela fé, Deus irá ajudar: "Pela confiança em Cristo, porque às vezes acham que uma doença é o fim de tudo. A gente fica muito firme naquele propósito: eu não nasci doente e não vou ficar doente, eu não aceito essa doença. A gente fica firme nisso e já não tem medo". B5 aborda também a questão da mudança do comportamento devido à religião: "Pela religião você tem um autocontrole dos seus nervos, um autocontrole de convivência, da alimentação. Mesmo que tenhamos o sufoco do dia-a-dia, sabemos que é passageiro".

\section{Considerações finais}

Os caminhos que o indivíduo percorre, ao enfrentar e procurar alívio para as mazelas decorrentes da hanseníase, tanto pelo aspecto clínico da doença como pelo aspecto social 
da estigmatização, desembocam em esquemas 'anestésicos' de esquecimento do sofrimento ou em medidas de resistência por acúmulo de ânimo e força de vontade. O lazer e as tarefas cotidianas foram realçados como meios de esquecer o sofrimento, o que verdadeiramente ajuda, se forte carga emocional perante às dificuldades e o acúmulo de desgostos for eliminada (enfrentamento focalizado no alívio de angústias emocionais). O papel da religião, salvo os casos em que os entrevistados não observam qualquer auxílio ou recorram a outros elementos, também insere a função de resistência ao problema vivido (enfrentamento focalizado na resolução dos problemas). Um exemplo de enfrentamento religioso focalizado na emoção é apontado por A2, que encontrou no asilo e na religião refúgio para problemas que enfrentava antes da doença. $\mathrm{O}$ enfrentamento religioso focalizado no problema dos entrevistados transparece na confiança de que a entidade divina irá ajudar por meio do contato que cada um mantém com o plano espiritual. Outros aspectos importantes, verificados nas entrevistas, incluem a mudança de conduta exigida pela religião, apontada por A5 e B5, e a atribuição de respostas, comentada por A1. A religião, portanto, exerce dupla função com relação aos anseios dos pacientes, seja como alívio emocional ou como fonte de recursos de enfrentamento relacionados à problemática do adoecer e da internação.

A diferença entre fé e religião é marcante em algumas entrevistas, exigindo do indivíduo não o mero comparecimento aos rituais e cultos religiosos, mas sim sua participação ativa em relação ao que acredita. A busca de auxílio na religião não se faz somente mediante os esquemas impostos pela instituição, asilar ou não; o indivíduo elabora seus próprios recursos, construídos ao longo de sua história.

O peso do estigma da 'lepra' não se expressou segundo a conotação bíblica, sendo até mesmo ignorado nos relatos dos ex-internos. Em meio aos atuais portadores de hanseníase, a mudança religiosa trouxe também novos discursos sobre a doença, como no caso da questão de limpeza e impureza, apontada por B2.

Não houve menção a confronto entre religião e terapêutica científica, sendo esta constantemente relembrada pelos pacientes. A importância dada à religião mencionada por alguns entrevistados não descartou a adesão ao tratamento médico. Entre os profissionais entrevistados - médicos e enfermeiros que atendem portadores de hanseníase no DHDS -, houve relatos sobre pacientes que abandonaram o medicamento pela exclusiva confiança na fé, aspecto prejudicial da religião ao tratamento dos doentes, enquadrado no estilo de enfrentamento religioso que Pargament (1997) define como delegante (deferring) e no qual enfatiza-se a dependência à autoridade externa e divina. Outro aspecto negativo é a carga de culpa e castigo que o indivíduo passa a suportar, por contrair a doença. Os profissionais apontaram a ajuda psicológica, a confiança na reabilitação e a orientação das comunidades religiosas no sentido de procurar serviços de saúde como aspectos positivos da religião, no tratamento de pacientes portadores de hanseníase. Verifica-se também maior valorização, por parte dos profissionais de saúde, do estilo de enfrentamento religioso cooperativo em relação ao estilo delegante.

O preconceito se faz presente no medo de declarar a condição de portador de hanseníase junto às comunidades religiosas, sob o risco de proscrição - a exceção de B2 e B5, que revelaram sua doença. Essa situação não se verifica entre os ex-internos, uma vez que todo o asilo e os indivíduos que o compunham compartilhavam o universo da hanseníase. 
As múltiplas formas de interferência da religião no processo saúde/doença se dão na construção dos significados e nas atitudes decorrentes da interiorização dos significantes religiosos, neles incluídos as regras das comunidades religiosa e secular das quais o indivíduo faz parte. Sua busca de amparo religioso, porém, também se faz na intimidade com o mistério, em que os problemas são debatidos com a instância espiritual no nível particular.

\section{NOTAS}

* Este artigo é resultado de pesquisa realizada para o Programa de Aprimoramento Profissional em Saúde Coletiva do Instituto de Saúde do Estado de São Paulo.

${ }^{1}$ A distinção entre colônia e rede diz respeito ao grupo entrevistado em história oral, tal como descreve Meihy (2000), em que a colônia é o traço preponderante em comum do grupo e a rede, a subdivisão da colônia, especificando-se as características dos entrevistados.

\section{REFERÊNCIAS}

CUNHA, Vívian da Silva.

O isolamento compulsório em questão: políticas de combate à lepra no Brasil (1920-1941).

Tese (Mestrado) - Fundação Oswaldo Cruz, Rio de Janeiro. 2005.

FOUCAULT, Michel.

Vigiar e punir. Petrópolis: Vozes. 1999.

GOFFMAN, Erwin.

Manicômios, prisões e conventos. São Paulo: Perspectiva. 1987.

KOENIG, Harold G.; McCULLOUGH, Michael E.; LARSON, David B.

Handbook of religion and health. New York: Oxford University Press. 2001.

MACIEL, Laurinda Rosa.

A construção social de uma enfermidade: o caso da lepra na Colômbia. História, Saúde, Ciências - Manguinhos. v.11, n.1, p.189-193. 2004.

MEIHY, José Carlos Sebe B.

Manual de história oral. São Paulo: Edições Loyola. 2000.

MONTEIRO, Yara. N.

Da maldição divina à exclusão social: um estudo da hanseníase em São Paulo. Tese (Doutorado) - Faculdade de Filosofia, Letras e Ciências Humanas, Universidade de São Paulo, São Paulo. 1995.

OBREGÓN, Diana.

The anti-leprosy campaign in Colombia: the rhetoric of hygiene and science, 1920-1940. História, Saúde, Ciências - Manguinhos. v.10, supl. 1, p.179-207. 2003.

OLIVIER, Henry. R.

On being diagnosed a 'leper': a paradigm of archetypal thinking. Southern Medical Journal, Birmingham, v.81, n.11, p.1426-1432. 1988.

PARGAMENT, Kenneth I.

The psychology of religion and coping. New York: The Guilford Press. 1997.

PARGAMENT, Kenneth I.; PARK, Crystal L. Merely a defense? The variety of religious means and ends. Journal of Social Issues, Malden, v.51, n.2, p.13-32. 1995.

ROSEN, George.

Uma história da saúde pública. São Paulo: Hucitec. 1994.

\section{$\rightarrow \rightarrow \rightarrow<<<$}

